\title{
ГІБРИДНІ ХІРУРГІЧНІ ВТРУЧАННЯ У ХВОРИХ З ПРИВОДУ ІШЕМІЧНОЇ ФОРМИ СИНДРОМУ ДІАБЕТИЧНОЇ СТОПИ
}

\author{
С. М. Діденко \\ Центр судинної хірургії, клінічна лікарня «Феофанія» ДУС, м. Київ

\section{THE HYBRID SURGICAL INTERVENTIONS IN PATIENTS, SUFFERING ISCHEMIC FORM OF DIABETIC FOOT SYNDROME}

\author{
S. M. Didenko \\ The Centre of Vascular Surgery, Clinical Hospital «Feofania», Kyiv
}

\begin{abstract}
Реферат
Вступ. Атеросклеротичне ураження нижніх кінцівок (НК) у хворих на цукровий діабет (ЦД) характеризується злоякісним перебігом. У хворих за стенотично-оклюзійного ураження артерій підколінно-гомілкового сегмента в поєднанні з ураженням стегнового сегмента потрібні складні тактичні й технічні рішення.

Мета. Проаналізувати результати застосування гібридних хірургічних втручань у хворих з приводу ішемічної фрорми синдрому діабетичної стопи (СДС).

Матеріали і методи. Проведене хірургічне лікування 79 хворих з приводу ішемічної фрорми СДС на тлі поєднаного стенотичнооклюзійного ураження артерій стегнового та підколінно-гомілкового сегментів.

Результати. Первинна прохідність зони реконструкції за умови застосування методів гібридної хірургії протягом періоду спостереження становила $91,11 \%$, частота збереження НК - 95,55\%.

Обговорення. Оптимальним методом хірургічного лікування хворих з приводу поєднаного стенотично-оклюзійного ураження підколінно-гомілкового та стегнового артеріального сегментів $є$ гібридна реконструктивна операція.

Висновок. При поєднанні оклюзії поверхневої стегнової артерії (ПСА) з стенотично-оклюзійним ураженням артерій підколінногомілкового сегмента у хворих за ішемічної форми СДС гібридна артеріальна реконструкція має суттєві переваги порівняно 3 ізольованою реконструкцією оклюзії ПСА, забезпечує регрес ішемії тканин, дозволяє достовірно довше зберегти НК.

Ключові слова: цукровий діабет; синдром діабетичної стопи; облітеруючий атеросклероз; ішемія нижньої кінцівки; гібридна хірургія.

Abstract

Introduction. Atherosclerotic affection of lower extremities in patients, suffering diabetes mellitus, is characterized by malignant course. In patients, suffering stenotic-occlusive affection of arteries in popliteo-crural segment in combination with affection of femoral segment complex the tactical and technical decisions are needed.

Objective. To analyze the results of application of the hybrid surgical interventions in patients, suffering ischemic form of the diabetic foot syndrome (DFS).

Materials and methods. There was conducted surgical treatment of 79 patients, suffering ischemic form of a DFS on background of combined stenotic-occlusive affection of arteries of femoral and popliteo-crural segments.

Results. Primary passability of the reconstruction zone while application of the hybrid surgery methods during period of observation have constituted $91.11 \%$, the lower extremities preservation rate $-95.55 \%$.

Discussion. Optimal method of surgical treatment in patients, suffering combined stenotic-occlusive affection of popliteo-crural and femoral arterial segments is a hybrid reconstructive operation.

Conclusion. In coexistent occlusion of superficial femoral artery with stenotic-occlusive affection of arteries of popliteo-crural segment in patients, suffering ischemic form of of the DFS, a hybrid arterial reconstruction has essential advantages, comparing with isolated reconstruction, it guarantees the tissue ischemia regress, permits to save the lower extremities longer trustworthily.

Keywords: diabetes mellitus; diabetic foot syndrome; obliterating atherosclerosis; ischemia of lower extremity; the hybrid surgery.
\end{abstract}

За даними ВОЗ, гангрена НК у хворих на џД виникає в 30 разів частіше, ніж у хворих за відсутності Щд. Не викликає сумнівів необхідність пошуку ефективних методів діагностики й лікування облітеруючих захворювань судин у пацієнтів при Цд $[1,2]$

Атеросклеротичне ураження НК у хворих на ЦД виникає на 10 - 15 років раніше, ніж за його відсутності, його перебіг більш швидкий і злоякісний, раніше й частіше з'являються тяжкі гнійно-некротичні усклад- нення. Особливістю діабетичного ураження артеріального русла НК $є$ багаторівневий стенотично-оклюзійний процес в артеріях середнього і малого діаметра (підколінна, гомілкові артерії, артерії стопи) та наявність діабетичної мікроангіопатії [3].

Частота ураження периферійних артерій у чоловіків і жінок при Цд однакова, тоді як при облітеруючому атеросклерозі за відсутності Цд частіше хворіють чоловіки. При Цд атеросклеротичний процес є дифуз- ним, схильний до полісегментарного ураження периферійних артерій.

Саме цією особливістю, а також наявністю діабетичної полінейропатії дослідники пояснюють особливість клінічних проявів хронічної ішемії тканин у хворих на ЦД біль в НК при фізичному навантаженні без переміжної кульгавості. Кровопостачання при атеросклерозі НК у хворих на Цд порушується переважно внаслідок зменшення колатерального кровообігу і виснаження судинного резерву [4]. 
Найбільш специфічними морфологічними ознаками ураження артерій у хворих на Цд є медіакальциноз Менкеберга та дифузний фіброз внутрішньої оболонки судин [5].

Особливо складні тактичні й технічні рішення потрібні у хворих за стенотично-оклюзійного ураження артерій підколінно-гомілкового сегмента в поєднанні з ураженням стегнового сегмента, у яких не можуть бути застосовані стандартні методи оперативних втручань $[6,7]$.

Мета дослідження: проаналізувати результати застосування гібридних хірургічних втручань у хворих 3 приводу ішемічної форми СДС.

\section{МАТЕРІАЛИ I МЕТОДИ ДОСЛІДЖЕННЯ}

Проведене хірургічне лікування 79 хворих з приводу ішемічної форми СДС на тлі поєднаного стенотично-оклюзійного ураження артерій стегнового та підколінно-гомілкового сегментів в Центрі судинної хірургіï у 2014 - 2017 рp. В усіх пацієнтів діагностовано ішемію тканин HK IV ступеня (за Fontaine). В усіх пацієнтів вимірювали сегментарний тиск (СТ), визначали кісточковоплечовий індекс (КПІ), проводили ультразвукове дуплексне сканування (УЗДС) артерій НК з вивченням кровотоку на апараті «Flex focus» виробництва «BK Medical». Ангіографію проводили шляхом пункції загальної стегнової артерії або ПСА під контролем ультразвуку з використанням ангіографічної системи «Euroampli ALIEN» виробництва «Eurocolumbus SRL». Проводили бактеріологічне дослідження вмісту ран стопи з визначенням чутливості мікроорганізмів до антибіотиків.

Пацієнти з багаторівневим ураженням артерій НК розподілені на дві групи. У 45 (57\%) пацієнтів (основна група) 3 метою корекції критичної ішемії тканин НК виконане гібридне втручання: відновлення прохідності стегнового артеріаль- ного сегмента 3 використанням одного 3 хірургічних способів (шунтування або ендартеректомія) в поєднанні з балонною ангіопластикою підколінної артерії, тібіоперонеального стовбура та гомілкових артерій в різних поєднаннях. У 34 (43\%) пацієнтів (контрольна група) відновлювали прохідність стегнового артеріального сегмента без втручання на артеріях підколінно-гомілкового сегмента (див. таблицю).

В контрольній групі у 30 хворих здійснена реконструкція стегнового артеріального сегмента шляхом шунтування, у 4 - ендартеректомії 3 пластикою артерії з використанням латки.

Операції шунтування в обох групах виконані з застосуванням синтетичних протезів або комбінованих шунтів (синтетичний протез та аутовенозна вставка). Прихильність до використання синтетичних протезів як шунтів ми пояснюємо необхідністю збереження великої підшкірної вени для можливого в подальшому аорто-коронарного або повторного периферійного шунтування, наявністю розсипного типу анатомії підшкірних вен НК або раніше виконаною венекомією.

Ендартеректомію виконували відкрито або з використанням кілець Vollmar. Як латку для пластики ПСА після ендартеректомії використовували сегмент однієї з приток великої підшкірної вени 3 метою збереження іiі неушкодженою або синтетичний матеріал.

Для ангіопластики вводили інтродюсер 6F через вже функціонуючий протез або ПСА. Застосовували периферійні балони діаметром 2, 2,5, 3 і 4 мм на коронарному провіднику 0,014'.

\section{РЕЗУЛЬТАТИ}

Протягом періоду спостереження, у середньому 12 міс, у 4 пацієнтів основної групи виник тромбоз зони стегново-підколінної реконструк- ціï. Пацієнтам здійснена тромбектомія 3 шунта, за даними ангіографії виявлений рестеноз артерій підколінно-гомілкового сегмента, виконана повторна ангіопластика, у 2 з них 3 хорошим результатом. В одного хворого регресу ішемії тканин НК досягти не вдалося, виконана ампутація на рівні гомілки. В одного хворого виконана ампутація НК на рівні стегна через нагноєння шунта.

У контрольній групі після виконання ізольованої артеріальної реконструкції стегнового сегмента (3 різних причин) протягом періоду спостереження в 11 пацієнтів виник тромбоз зони стегново-підколінної реконструкції. Пацієнтам здійснена тромбектомія з шунта, за даними ангіографії встановлене багаторівневе стенотично-оклюзійне ураження артерій підколінно-гомілкового сегмента. У 6 хворих виконана ангіопластика, у 4 - 3 позитивним результатом, у 2 - висока ампутація НК. 35 хворих, яким ангіопластику не виконували, у 4 - здійснена висока ампутація НК

Таким чином, первинна прохідність зони стегнової реконструкції у пацієнтів основної групи при застосуванні методів гібридної хірургії протягом періоду спостереження становила 91,11\%, частота збереження НК - 95,55\%. У пацієнтів контрольної групи після ізольованої реконструкції стегнового артеріального сегмента прохідність зони реконструкції становила 67,65\%, частота збереження НК - 82,35\%.

\section{ОБГОВОРЕННЯ}

За поєднаного стенотично-оклюзійного ураження стегнового та підколінно-гомілкового сегментів у хворих при ішемічній формі СДС потрібні складні тактичні й технічні рішення. Застосування стандартних методів для відновлення прохідності оклюзованого стегнового артеріального сегмента за наявності стенотично-оклюзійного уражен-

Види гібридних оперативних втручань

\begin{tabular}{|c|c|c|}
\hline Відкрита реконструкція стегнового сегмента & $\begin{array}{c}\text { Кількість } \\
\text { хворих }\end{array}$ & Сегмент ангіопластики \\
\hline \multirow{4}{*}{ Стегново-підколінне шунтування } & \multirow{4}{*}{40} & Тібіоперонеальний стовбур і передня великогомілкова артерія - 19 \\
\hline & & Підколінна і задня великогомілкова артерії -6 \\
\hline & & Тібіоперонеальний стовбур і задня великогомілкова артерія -6 \\
\hline & & Передня великогомілкова і малогомілкова артерії - 9 \\
\hline $\begin{array}{c}\text { Ендартеректомія з пластикою артерії } 3 \\
\text { використанням латки }\end{array}$ & 5 & Тібіоперонеальний стовбур і передня великогомілкова артерія - 3 \\
\hline
\end{tabular}


ня артерій підколінно-гомілкового сегмента часто не забезпечуе позитивний результат. 3 одного боку, стенотично-оклюзійне ураження артерій підколінно-гомілкового сегмента суттєво зменшує ємність приймаючого русла і $є$ провокуючим чинником тромбозу зони реконструкції стегнового сегмента; 3 іншого, наявність перешкоди між реконструйованою ПСА та судинами стопи зумовлює недостатню реваскуляризацію стопи. Якщо раніше за таких ситуацій ми були змушені виконувати

\section{REFERENCES}

1. Nikulnikov PI, Bycaj AN, Ratushnjuk AV, Liksunov AV. Osobennost hirurgicheskoj taktiki pri mnogourovnevyh okkljuzionno-stenoticheskih porazhenijah bedrenno-bercovogo arterial'nyh segmentov. Kharkivska hirurhichna shkola. 2013;3:148-51. [In Russian].

2. Pityk Al. Alternativnye podhody k endovaskuljarnoj revaskuljarizacii nizhnih konechnostej u bolnyh s kriticheskoj ishemiej. Serce i sudini. 2015;1(49):70-6. [In Russian].

3. Mishalov VG, Chernjak VA. Lechenie kriticheskoj ishemii nizhnih konechnostej u bolnyh s sochetannymi mnogojetazhnymi porazhenijami aorty i ee vetvej. Vestn neotlozh. i vosstanovit mediciny. 2010;3:377-9. [In Russian].

4. Gandini R, Uccioli L, Spinelli A, et al. Alternative techniques for treatment of complex below-the knee arterial occlusions in diabetic patients with critical limb ischemia. Cardiovasc Intervent Radiol. 2013;36:75-83.
5. Dos Santos V, Alves C, Fidelis C. Arteriographic findings in diabetic and nondiabetic patients with critical limb ischemia. Rev Assoc Med Bras. 2013;59(6):557-62.

6. Ruiter MS, van Golde JM, Schaper NC, et al. Diabetes impairs arteriogenesis in the peripheral circulation: review of molecular mechanisms. Clin Sci (Lond). 2010;119(6):225-38.

7. Setacci C, Sirignano P, Galzerano G, et al. Endovascular first as «preliminary approach» for critical limb ischemia and diabetic foot. $J$ Cardiovasc Surg (Torino). 2013;(54):679-84. 